\title{
The contribution of conservation biological control method to integrated plant protection and organic farming
}

\section{Konserwacyjna metoda biologiczna wsparciem integrowanej ochrony roślin i rolnictwa ekologicznego}

\author{
Danuta Sosnowska*
}

\section{Summary}

Biological control methods using viruses, microorganisms and macroorganisms to control pests (plant pests, pathogens and weeds) are one of the alternative means to chemical plant protection and they are considered as the priority activities in the Integrated Pest Management (IPM). A small number of biopesticides registered in Poland, especially for field crops, causes interest in the conservation biological method based on the human-modified agricultural landscape in order to create appropriate conditions for the development of beneficial organisms in the environment. This publication presents various human activities in the agricultural environment aimed at supporting the role of beneficial organisms.

Key words: biocontrol; integrated plant protection

\section{Streszczenie}

Metody biologiczne polegające na wykorzystaniu wirusów, mikroorganizmów i makroorganizmów do zwalczania agrofagów (szkodników roślin, patogenów i chwastów) są jedną z alternatywnych metod w stosunku do chemicznych środków ochrony roślin i należą do priorytetowych działań w integrowanej ochronie roślin (IPM - Integrated Pest Management). Niewielka ilość zarejestrowanych w Polsce biopreparatów, szczególnie w uprawach polowych powoduje zainteresowanie konserwacyjną metodą biologiczną polegającą na modyfikacji krajobrazu rolniczego przez człowieka w celu stworzenia odpowiednich warunków dla rozwoju organizmów pożytecznych w środowisku. W niniejszej publikacji przedstawiono różne działania człowieka w środowisku rolniczym mające na celu wsparcie roli organizmów pożytecznych.

Słowa kluczowe: biologiczna ochrona roślin; integrowana ochrona roślin

Instytut Ochrony Roślin - Państwowy Instytut Badawczy

Zakład Metod Biologicznych i Rolnictwa Ekologicznego

Władysława Węgorka 20, 60-318 Poznań

*corresponding author: danuta.sosnowska@iorpib.poznan.pl 


\section{Wstęp / Introduction}

Już w latach 70. XX wieku pisano, że ochrona roślin stała się jednym z elementów zintegrowanej działalności, której celem jest najwyższa i najlepsza produkcja roślinna uwzględniająca wszelkie potrzeby ochrony środowiska i zdrowia człowieka (Sandner 1971). Obecnie powraca się do tych wartości poprzez wprowadzanie integrowanej ochrony roślin wynikającej z postanowień Dyrektywy Parlamentu Europejskiego i Rady 2009/128/WE z dnia 21 października 2009 r. ustanawiającej ramy wspólnotowego działania na rzecz zrównoważonego stosowania pestycydów (Dz. Urz. UE L 309/71 z 24.11.2009, s. 71, z późn. zm.). Wprowadziła ona od 1 stycznia 2014 roku obowiązkowe stosowanie przez wszystkich profesjonalnych użytkowników środków ochrony roślin zasad integrowanej ochrony roślin. Ponadto wchodzi w życie kolejny Krajowy Plan Działania (KPD) na rzecz ograniczenia ryzyka związanego ze stosowaniem środków ochrony roślin na lata 2018-2022. W dokumencie tym przyjęto, że kluczowym celem dla Polski będzie upowszechnianie zasad integrowanej ochrony roślin oraz wdrożenie tych zasad, w szczególności przez promowanie niechemicznych metod ochrony, co ma prowadzić do zmniejszenia zależności produkcji roślinnej od chemicznych środków ochrony roślin i w efekcie ogranicza ryzyko związane $\mathrm{z}$ ich użyciem.

Bardzo ważnym elementem metod niechemicznych są metody biologiczne, polegające na wykorzystaniu wirusów, mikroorganizmów (bakterie, grzyby) oraz makroorganizmów (nicienie, drapieżne roztocze oraz pasożytnicze i drapieżne owady) do zwalczania agrofagów (szkodników roślin, patogenów i chwastów). Biologiczne metody zwalczania są jedną $\mathrm{z}$ alternatywnych metod w stosunku do chemicznych środków ochrony roślin. Wiadomo, że co roku do zwalczania szkodników stosuje się na świecie około 3 mld ton pestycydów (Messing i Broudeur 2018). Nie jest to obojętne dla środowiska. W ostatnich latach zwiększył się asortyment pożytecznych makroorganizmów dzięki działalności firm prywatnych (van Lenteren i wsp. 2018). Zwiększa się również sprzedaż mikrobiologicznych środków ochrony roślin w świecie, jednak nadal stanowi tylko 2,5\% w porównaniu ze sprzedażą chemicznych środków ochrony roślin (Evans 2008). W latach 2005-2010 udział środków biologicznych w światowym rynku pestycydów wzrósł do 4,2\% (Ravensberg 2011). Jednak w Polsce, lista zarejestrowanych biopreparatów jest nadal niewielka i wynosi tylko 13 środków (tab. 1). Znacznie więcej stosuje się makroorganizmów, które nie podlegają rejestracji. W związku z powyższym powraca się do sprawdzonych metod biologicznych, które mogą wspomóc integrowaną ochronę roślin. Jedną z nich jest konserwacyjna metoda biologiczna.

\section{Biologiczne metody ochrony roślin / Biological control methods}

Jedna $\mathrm{z}$ zasad integrowanej ochrony roślin mówi, że nad chemiczne metody zwalczania organizmów szkodliwych przedkładać należy metody biologiczne i inne niechemiczne, jeżeli zapewniają one ochronę przed organizmami szkodliwymi. W Rozporządzeniu Parlamentu Europejskiego i Rady (WE) nr 1107/2009 z dnia 21 października 2009 r. (Dz. U. L 309 z 24.11.2009, s. 1) czytamy, że ,w celu zapewnienia wysokiego poziomu ochrony zdrowia ludzi i zwierząt oraz środowiska, środki ochrony roślin powinny być stosowane w sposób właściwy, zgodnie z wydanym zezwoleniem z uwzględnieniem zasad integrowanej ochrony roślin, przy czym zawsze gdy jest to możliwe, priorytetowo należy traktować niechemiczne i naturalne rozwiązania alternatywne". Jest to wyraźne zielone światło w kierunku stosowania metod biologicznych.

Metody biologiczne polegają na wykorzystaniu naturalnych zjawisk występujących w przyrodzie. Pożyteczne mikroorganizmy (bakterie i grzyby), wirusy, makroorganizmy (nicienie, drapieżne i pasożytnicze owady, drapieżne roztocze), owadożerne ptaki i ssaki ograniczają na co dzień liczebność agrofagów (szkodników roślin, patogenów i chwastów) i zapobiegają masowym pojawom szkodników, chorób roślin i chwastów. Inaczej mówiąc zwalczanie biologiczne polega na wykorzystaniu przez człowieka zjawisk pasożytnictwa i drapieżnictwa występujących w przyrodzie i sterowaniu nimi. Wymaga ono znajomości ekologii, biologii i systematyki organizmów szkodliwych oraz ich wrogów naturalnych.

W Polsce asortyment biologicznych środków ochrony roślin składa się z preparatów opartych na wirusach owadobójczych (2 biopreparaty), grzybach owadobójczych (2 biopreparaty), bakteriach owadobójczych (3 biopreparaty), grzybach drożdżopodobnych do zwalczania sprawców chorób (1 biopreparat), bakterii do zwalczania sprawców chorób (1 biopreparat), grzybach mykopasożytniczych (2 biopreparaty) i grzybach antagonistycznych do zwalczania sprawców chorób (2 biopreparaty) (tab. 1). Głównie stosuje się te biopreparaty w sadach, uprawach warzyw, lasach i uprawach pod osłonami. W warunkach polowych zarejestrowano tylko dwa biopreparaty oparte na bakteriach Bacillus thuringiensis subsp. tenebrionis (Novodor SC) i Bacillus thuringiensis var. kurstaki (Dipel WG) do zwalczania szkodników roślin. Jeszcze niedawno nie było w tym spisie bioinsektycydów zawierających w swoim składzie grzyby owadobójcze. Od dwóch lat ten asortyment zaczyna się poszerzać i na razie zarejestrowane są dwa bioinsektycydy oparte na grzybach owadobójczych Beauveria bassiana (Naturalis) i Isaria fumosorosea (Preferal), jednak znajdują zastosowanie tylko w uprawach pod osłonami. W uprawach polowych do zwalczania szkodników roślin nie zarejestrowano bioinsektycydów opartych na grzybach owadobójczych. Można 
natomiast stosować entomofagi. Jednym z nich jest pasożytnicza błonkówka - kruszynek (Trichogramma evanescens lub Trichogramma brassicae) stosowany w uprawach kukurydzy do zwalczania omacnicy prosowianki (Bereś 2015a, b).

W uprawach polowych do ograniczania sprawców chorób zarejestrowano biopreparaty opare na grzybach pasożytniczych: Coniothyrium minitans (Contans WG) oraz Pythium oligandrum (Polyversum WP). Zwalczają one sprawców i zapobiegają pojawieniu się takich chorób, jak: zgnilizna twardzikowa, fuzarioza, szara pleśń, rizoktonioza, mączniak prawdziwy i wiele innych, również w uprawach ekologicznych (tab. 1).

W uprawach ekologicznych zarejestrowano dwa biopreparaty oparte na grzybie antagonistycznym Trichoderma harzianum (Trianum G i Trianum P) do ograniczania sprawców chorób na pomidorze, sałacie i ogórku.

Biopreparaty oparte na wirusach owadobójczych zarejestrowano w sadach do zwalczania owocówki jabłkóweczki. Są to: Carpovirusine Super SC i Madex Max. Ponadto do stosowania w lasach zarejestrowano biopreparat oparty na bakterii B. thuringiensis var. kurstaki (Foray 76B) (tab. 1).

Niewielki asortyment biopreparatów do ochrony upraw polowych może być zastąpiony działaniami, które będą wspomagać opór środowiska. Takim działaniem człowieka może być uprawa roślin, które są źródłem pokarmu dla organizmów pożytecznych, często są dla nich schronieniem czy roślinami miododajnymi (np. robinia akacjowa, gryka zwyczajna, ogórecznik lekarski) oraz tworzenie infrastruktury ekologicznej obejmującej miedze, zadrzewienia śródpolne, oczka wodne, zakrzewienia czy nawet zawieszanie budek lęgowych dla ptaków. Wspierają one działanie czynników biologicznych w środowisku i nawet przy braku środków biologicznych mogą powodować naturalne działanie tych czynników prowadzące do ograniczania populacji wielu szkodników. W sprzyjających warunkach (temperatura i wilgotność) można nawet zaobserwować epizoocje, czyli masowe zamieranie np. mszyc spowodowane działaniem grzybów należących do rodziny owadomorków (Entomophthoraceae). Działania wspomagające skuteczność czynników biologicznych w środowisku są elementem konserwacyjnej metody biologicznej. Jest ona wsparciem nie tylko integrowanej ochrony roślin, ale również rolnictwa ekologicznego. Głównym założeniem ochrony roślin w rolnictwie ekologicznym nie jest zwalczanie chorób i szkodników, lecz stworzenie odpowiednich warunków dla prawidłowego wzrostu roślin, aby te agrofagi nie rozwijały się w uprawie lub aby ich wpływ na plonowanie był minimalny (Tomalak i Zaremba 2004).

\section{Konserwacyjna metoda biologiczna / Conservation biological control method}

Konserwacyjna metoda biologiczna polega na modyfikacji krajobrazu rolniczego przez człowieka w celu stworzenia odpowiednich warunków dla rozwoju organizmów pożytecznych w środowisku.
Od lat wiadomo, że czynniki biologiczne, takie jak: wirusy, bakterie i grzyby chorobotwórcze w warunkach naturalnych redukują populacje szkodników roślin. $\mathrm{Na}$ ich skuteczność wpływa wiele czynników. Głównymi czynnikami prowadzącymi do ubożenia zarówno gatunkowego, jak i ilościowego mikroorganizmów pożytecznych jest ingerencja człowieka i przekształcenia przezeń środowisk naturalnych. Badania Bałazego (2002) wykazały bardzo silne zubożenia zasobów grzybów entomopatogenicznych w uprawach jednorocznych. Wyraża się ono wysoce istotnym obniżeniem liczby zakażonych owadów, a w konsekwencji również wytwarzanych zarodników, w porównaniu z lasami, zadrzewieniami czy wieloletnimi uprawami lucerny oraz łąkami. Również skład gatunkowy tych patogenów był na polach ornych znacznie silniej uproszczony niż w środowiskach o większym udziale elementów naturalnych, takich jak zadrzewienia lub zbiorowiska szuwarowe i trawiaste (Bałazy 2002).

Tereny rolnicze okolic Turwi pod Poznaniem pokryte śródpolnymi zadrzewieniami, które były nasadzone w 19. wieku przez ówczesnego właściciela generała Dezyderego Chłapowskiego wzbogaciły bioróżnorodność tego środowiska (Karg i Bałazy 2009). W badaniach prowadzonych na tym terenie w latach 60. ubiegłego wieku przez Stację Badawczą Instytutu Środowiska Rolniczego i Leśnego Polskiej Akademii Nauk, stwierdzono znaczący, pozytywny wpływ zadrzewien śródpolnych na naturalną redukcję stonki ziemniaczanej. Wykazano między innymi, że wśród czynników redukujących tego szkodnika znaczny był udział płazów. Ponadto w zadrzewieniach zimuje wiele gatunków owadów drapieżnych i parazytoidów, a także mikroorganizmów, które ograniczają populacje owadów szkodliwych na polach w sąsiedztwie.

Efektywność grzybów owadobójczych i nicieniobójczych jest uzależniona od wielu czynników znajdujących się w glebie. Jednym z nich są nawozy organiczne, jak: słoma, obornik czy gorczyca. O roli słomy po uprawie zbóż jako nawozu organicznego przekonano się w ostatnich latach. Słoma zwiększa żyzność gleby, jest źródłem energii i składników pokarmowych dla żyjących w glebie drobnoustrojów oraz zwiększa zawartość makro- i mikroelementów (Kuszelewski 1970; Popławski 1996). Sosnowska i Banaszak $(1998,2000)$ obserwowali na polach buraka cukrowego pod Toruniem większe spasożytowanie jaj mątwika burakowego przez grzyby na poletkach nawożonych słomą niż na polach nawożonych obornikiem. Obornik wpływa korzystnie na tworzenie struktury gleby, poprawia stosunki powietrzno-wodne i gospodarkę wodną. Ponadto zwiększa aktywność biologiczną gleby i powoduje wzrost jej kompleksu żywieniowego (Grzebisz i Gała 1995). Obornik jest również źródłem azotu (Grzebisz 1996). Sosnowska (2003) zauważyła mniejszą efektywność grzybów nicieniobójczych na polach nawożonych obornikiem, natomiast Tkaczuk (2008) stwierdził, że stosowanie 
Tabela 1. Wykaz biologicznych środków ochrony roślin zarejestrowanych w Polsce Table 1. List of biopesticides registered in Poland

\begin{tabular}{|c|c|c|}
\hline $\begin{array}{l}\text { Nazwa } \\
\text { Name }\end{array}$ & $\begin{array}{l}\text { Substancja czynna } \\
\text { Active substance }\end{array}$ & $\begin{array}{l}\text { Zastosowanie } \\
\text { Application }\end{array}$ \\
\hline BoniProtect & Aureobasidium pullulans & $\begin{array}{l}\text { jabłonie i grusze do zwalczania chorób } \\
\text { apple and pear trees for disease control }\end{array}$ \\
\hline $\begin{array}{l}\text { Carpovirusine } \\
\text { Super SC }\end{array}$ & $\begin{array}{l}\text { wirus } \mathrm{z} \text { rodziny Baculoviridae } \\
\text { virus from the family Baculoviridae }\end{array}$ & $\begin{array}{l}\text { sady: owocówka jabłkóweczka; również w uprawach ekologicznych } \\
\text { orchards: codling moth; also in organic crops }\end{array}$ \\
\hline Madex Max & Cydia pomonella granulovirus & $\begin{array}{l}\text { sady: owocówka jabłkóweczka; również w uprawach ekologicznych } \\
\text { orchards: codling moth; also in organic crops }\end{array}$ \\
\hline Contans WG & Coniothyrium minitans & $\begin{array}{l}\text { rzepak ozimy, rośliny warzywne, rośliny ozdobne, tytoń: Sclerotinia } \\
\text { sclerotiorum; również w uprawach ekologicznych } \\
\text { winter oilseed rape, vegetable plants, ornamental plants, tobacco: } \\
\text { Sclerotinia sclerotiorum; also in organic crops }\end{array}$ \\
\hline Dipel WG & $\begin{array}{l}\text { Bacillus thuringiensis var. kurstaki, } \\
\text { szczep ABTS } \\
\text { Bacillus thuringiensis var. kurstaki, } \\
\text { strain ABTS }\end{array}$ & $\begin{array}{l}\text { rośliny warzywne: gąsienice Pieris brassicae, Pieris rapae, Mamestra } \\
\text { brassicae; również w uprawach ekologicznych } \\
\text { vegetable plants: caterpillars of Pieris brassicae, Pieris rapae, } \\
\text { Mamestra brassicae; also in organic crops }\end{array}$ \\
\hline Serenade ASO & $\begin{array}{l}\text { Bacillus subtilis, } \\
\text { szczep QST713-13,96 g } \\
\text { Bacillus subtilis, } \\
\text { strain QST713-13,96 g }\end{array}$ & $\begin{array}{l}\text { truskawka, fasola, pomidor, grusza: Botrytis cinerea, Pseudomonas } \\
\text { siringae, Erwinia amylovora, mączniak prawdziwy; również } \\
\text { w uprawach ekologicznych } \\
\text { strawberry, bean, tomato, pear: Botrytis cinerea, Pseudomonas sirin- } \\
\text { gae, Erwinia amylovora, powdery mildew; also in organic crops }\end{array}$ \\
\hline Novodor SC & Bacillus thuringiensis subsp. tenebrionis & $\begin{array}{l}\text { ziemniaki: stonka ziemniaczana; również w uprawach ekologicznych } \\
\text { potatoes: Colorado potato beetle; also in organic crops }\end{array}$ \\
\hline Foray $76 \mathrm{~B}$ & Bacillus thuringiensis var. kurstaki & $\begin{array}{l}\text { lasy: szkodniki } \\
\text { forests: pests }\end{array}$ \\
\hline Naturalis & $\begin{array}{l}\text { Beauveria bassiana, } \\
\text { szczep ATCC } 74040-0,185 \mathrm{~g} \\
\text { Beauveria bassiana, } \\
\text { strain ATCC } 74040-0,185 \mathrm{~g}\end{array}$ & $\begin{array}{l}\text { truskawka, pomidor, papryka, ogórek: wciornastki, przędziorki, } \\
\text { mączliki; również w uprawach ekologicznych } \\
\text { strawberry, tomato, pepper, cucumber: thrips, mites, whiteflies; } \\
\text { also in organic crops }\end{array}$ \\
\hline $\begin{array}{l}\text { Trianum G } \\
\text { Trianum P }\end{array}$ & $\begin{array}{l}\text { Trichoderma harzianum Rifai, } \\
\text { szczep T-22-10 g } \\
\text { Trichoderma harzianum Rifai, } \\
\text { strain T-22-10 g }\end{array}$ & $\begin{array}{l}\text { pomidor, sałata, ogórek: Fusarium oxysporum, Rhizoctonia solani, } \\
\text { zgnilizny; tylko w uprawach ekologicznych } \\
\text { tomato, lettuce, cucumber: Fusarium oxysporum, Rhizoctonia solani, } \\
\text { root rot of plants; only in organic crops }\end{array}$ \\
\hline Polyversum WP & Pythium oligandrum & $\begin{array}{l}\text { warzywa i rośliny ozdobne pod osłonami: Fusarium spp., fytoftoro- } \\
\text { za, Botrytis cinerea, Rhizoctonia solani, Sclerotinia sclerotiorum, } \\
\text { zgorzele, mączniak prawdziwy i rzekomy; również w uprawach } \\
\text { ekologicznych } \\
\text { vegetables and ornamental plants under covers: Fusarium spp., Phy- } \\
\text { tophthora diseases, Botrytis cinerea, Rhizoctonia solani, Sclerotinia } \\
\text { sclerotiorum, plant gangrene, powdery mildew, downy mildew; } \\
\text { also in organic crops }\end{array}$ \\
\hline Preferal WG & Isaria fumosorosea & $\begin{array}{l}\text { warzywa i rośliny ozdobne pod osłonami: mączliki } \\
\text { vegetables and ornamental plants under covers: whiteflies }\end{array}$ \\
\hline
\end{tabular}

obornika i bezorkowy system uprawy gleby wzbogacają skład gatunkowy i ilościowy jednostek infekcyjnych grzybów owadobójczych należących do strzępczaków w glebie. Potencjał infekcyjny grzybów patogenicznych ograniczały nawozy mineralne, chemiczne środki ochrony roślin i zanieczyszczenia gleb metalami ciężkimi (Tkaczuk 2008). W Niemczech na polach nawożonych słomą z jęczmienia, grzyby pasożytnicze redukowały $29 \%$ populacji mątwika burakowego, a na polach z gorczycą 30-35\% populacji (Hoffman-Hergarten i Sikora 1993). Z kolei w USA Jaf- fee i wsp. (1994) obserwowali ujemny wpływ słomy na rozwój grzyba nicieniobójczego Hirsutella rhossiliensis. Sosnowska (2003) zaobserwowała, że nawozy organiczne, takie jak słoma pożniwna $\mathrm{z}$ jęczmienia jarego i mulcz z gorczycy stymulowały aktywność grzybów nicieniobójczych powodując zwiększenie spasożytowania jaj w cystach mątwika burakowego (Heterodera schachtii). Wiadomo, że gorczyca jest znanym nawozem zielonym i alternatywnym źródłem materii organicznej (Grzebisz i Gała 1995). Uprawiane rośliny mają również wpływ na efektywność 
grzybów nicieniobójczych w glebie, np. uprawa kapusty bardziej sprzyjała rozwojowi tych grzybów w ryzosferze korzeniowej niż uprawa pomidora (Sosnowska 2003).

Stosowane technologie uprawy mogą stymulować aktywność patogenów grzybowych np. największe spasożytowanie jaj mątwika przez grzyby pasożytnicze obserwowano na polach buraka cukrowego w płodozmianie trzyletnim niż dwuletnim (Sosnowska 2003). Również obserwowano tam większe zróżnicowanie gatunkowe grzybów.

Znajomość tych zależności i procesów może być wykorzystana w uprawie roślin np. w gospodarstwach ekologicznych, gdyż działania mające na celu zwiększenie aktywności pożytecznych organizmów glebowych należą do priorytetów ochrony roślin w tych gospodarstwach. Działania opisane powyżej wpisują się w filozofię rolnictwa ekologicznego, które jest systemem gospodarowania o zrównoważonej produkcji roślinnej i zwierzęcej, który łączy przyjazne środowisku praktyki gospodarowania, wspomagając wysoki stopień różnorodności biologicznej wykorzystujący naturalne procesy oraz zapewniający właściwy dobrostan zwierząt.

Inną ważną przyczyną ubożenia zasobów mikroorganizmów chorobotwórczych są ich wymagania związane z mikroklimatem środowisk, a zwłaszcza warunki wilgotnościowe. Ponad 90\% gatunków grzybów owadobójczych preferuje środowiska silnie lub umiarkowanie uwilgotnione. Dlatego bogatsze zgrupowania tych grzybów można znaleźć na terenach mokradłowych, bądź w skupiskach roślinności wielowarstwowej (zadrzewienia, zakrzewienia, szuwary) (Bałazy 2002). Wpływ temperatury i wilgotności na efektywność grzybów owadobójczych badało wielu naukowców (Miętkiewski i wsp. 1994; Fiedler i Sosnowska 2006; Hussein i wsp. 2014). Wiadomo, że dla rozwoju grzybów owadobójczych i ich skuteczności wymagana jest odpowiednia temperatura i wilgotność. Sharififard i wsp. (2012) obserwowali największą skuteczność grzyba $B$. bassiana przy wilgotności $75 \%$ w przedziale temperatur $25-30^{\circ} \mathrm{C}$. Słabszy wzrost I. fumosorosea i $B$. bassiana obserwowano w przedziale temperatur $10-15^{\circ} \mathrm{C}$, a najlepszy w przedziałach $20-25^{\circ} \mathrm{C}$ (Yeo i wsp. 2003). W warunkach polowych trudno jest regulować te parametry. Jednak znane są przypadki silnych epizoocji (masowego zamierania) kolonii mszyc pod wpływem grzybów owadobójczych należących do owadomorków (Steenberg i Eilenberg 1995). Jedynie w warunkach upraw pod osłonami można regulować temperaturę i wilgotność w celu zwiększenia skuteczności biopreparatów stosowanych do zwalczania szkodników (Sosnowska 2018). Dlatego w takich uprawach zarejestrowano najwięcej biopreparatów na świecie.

Środowisko rolnicze wpływa na występowanie pasożytniczych i drapieżnych owadów. Badania Rzańskiej-Wieczorek (2017, dane niepublikowane) wykazały, że najwięcej muchówek $\mathrm{z}$ rodziny bzygowatych odłowiono na drodze śródpolnej na terenie poletek Polowej Stacji Doświadczalnej Instytutu Ochrony Roślin - Państwowego
Instytutu Badawczego w Winnej Górze. Dużą liczbę tych osobników zarejestrowano także na miedzy. Wiadomo, że larwy (stadium drapieżne) tych muchówek odżywiają się głównie mszycami i ich obecność w środowisku jest niezmiernie ważna. Postacie dorosłe odżywiają się pyłkiem i nektarem kwiatowym, dlatego pozostawienie enklaw roślin dziko rosnących lub celowe wysiewanie roślin miododajnych (np. facelia), które dostarczają bzygowatym i innym owadom pożytecznym niezbędnego dla ich rozwoju pokarmu jest działaniem wspomagającym ich skuteczność w warunkach polowych (Tomalak i Sosnowska 2008).

W warunkach naturalnych wiele gatunków owadów pożytecznych (drapieżnych i pasożytniczych) ogranicza populacje wielu szkodników roślin. Znana jest rola biedronek w ograniczaniu populacji mszyc. Jedna larwa biedronki w ciągu całego swojego rozwoju (około 30 dni) może zlikwidować od 100 do nawet 200 mszyc, a chrząszcz biedronki zjada dziennie od około 30 do 250 mszyc (Tomalak i Sosnowska 2008). Należy wspomagać rozwój pożytecznych entomofagów poprzez stworzenie im dogodnych warunków do rozwoju i schronienia. Naturalnymi ostojami dla tych owadów są rośliny, które charakteryzują się silnie wonnymi kwiatami oraz długim i obfitym okresem kwitnienia.

\section{Podsumowanie / Summary}

Stosowanie integrowanej ochrony roślin w Polsce powoduje, że zwiększa się wśród producentów rolnych i firm fitofarmaceutycznych zainteresowanie wprowadzaniem biologicznych środków ochrony roślin. Ważne jest również opracowanie strategii wspierających działanie czynników biologicznych w środowisku. O czynnikach ograniczających rejestrację biopreparatów opartych na bakteriach ograniczających zarazę ogniową w sadach pisali Mikiciński i Sobiczewski (2018). Jednym z nich jest kosztowny proces rejestracji, który trwa latami. Dlatego wszystkie działania wspomagające skuteczność czynników biologicznych w środowisku mają ogromne znaczenie. Metoda konserwacyjna jest tego dowodem. Pozostawienie miedz, zadrzewień śródpolnych, wysiewanie roślin miododajnych będzie wsparciem działania organizmów pożytecznych w środowisku rolniczym. Inna działalność człowieka, jak np. stosowanie nawozów organicznych, płodozmian, systemy uprawy (orkowa, bezorkowa) i przede wszystkim stosowanie selektywnych chemicznych środków ochrony roślin ma również ogromne znaczenie w tej metodzie.

Ważne jest także podniesienie świadomości i wiedzy rolników w tym zakresie poprzez szkolenia i upowszechnianie wiedzy w formie publikacji w dostępnych rolniczych czasopismach. Szkolenia powinny uwzględniać między innymi zagadnienia doskonalenia struktury przestrzennej gospodarstwa w celu zwiększenia dostępnej bioróżnorodności, sprawnego prognozowania i sygnalizacji pojawu agrofagów. 


\section{Literatura / References}

Bałazy S. 2002. Grzyby entomopatogeniczne na obszarach rolniczych. W: Działalność naukowa - wybrane zagadnienia 14. Polska Akademia Nauk, Warszawa: 120-124.

Bereś P.K. 2015a. Kruszynkiem w omacnicę. Top Agrar Polska 3: 138-141.

Bereś P.K. 2015b. Biologiczna metoda zwalczania omacnicy prosowianki. Farmer 6: 77-81.

Dyrektywa Parlamentu Europejskiego i Rady 2009/128/WE z dnia 21 października 2009 r. ustanawiająca ramy wspólnotowego działania na rzecz zrównoważonego stosowania pestycydów (Dz. Urz. UE L 309/71 z 24.11.2009, s. 71, z późn. zm.).

Evans J. 2008. Biopesticides: from cult to mainstream. Agrow Magazine 27: 11-14.

Fiedler Ż., Sosnowska D. 2006. Wpływ temperatury na efektywność patogenów grzybowych w ograniczaniu liczebności różnych stadiów rozwojowych Frankliniella occidentalis (Pergande). [The influence of temperature on effectiveness of the fungi pathogens in reduction of difference stages of Frankliniella occidentalis (Pergande)]. Progress in Plant Protection/Postępy w Ochronie Roślin 46 (2): 487-490.

Grzebisz W. 1996. Nawożenie azotowe buraków cukrowych. Agrochemia 2: 17-18.

Grzebisz W., Gała Z. 1995. O siewie buraków myśleć jesienią. Top Agrar Polska. Magazyn Nowoczesnego Rolnictwa 10: 34-37.

Hoffman-Hergarten S., Sikora R.A. 1993. Studies on increasing the activity of nematode-trapping fungi against early attack by Heterodera schachtii using organic fertilizer. Zeitschrift fur Pflanzenkrankheiten und Pflanzenschut 100: 170-175.

Hussein R.H.M., Ezzat S.M., Nabil H.A. 2014. Effects of some abiotic factors on mycelial growth rates of Isaria fumosorosea Wize and laboratory evaluation against Planococcus citri (Risso). Journal of Entomology 11 (6): 338-344. DOI: 10.3923/je.2014.338.344.

Jaffee B.A., Ferris H., Stapleton J.J., Norton M.V.K., Muldoon A.E. 1994. Parasitism of nematodes by the fungus Hirsutella rhossiliensis as affected by certain organic amendments. Journal of Nematology 26 (2): 152-161.

Karg J., Bałazy S. 2009. Wpływ struktury krajobrazu na występowanie agrofagów i ich antagonistów w uprawach rolniczych. [Effect of landscape structure on the occurrence of agrophagous pests and their antagonists]. Progress in Plant Protection/Postępy w Ochronie Roślin 49 (3): 1015-1034.

Kuszelewski L. 1970. Studia nad słomą jako nawozem organicznym. Roczniki Nauk Rolniczych, Seria A, Produkcja roślinna 97: 79-94.

Messing R., Broudeur J. 2018. Current challenges to the implementation of classical biological control. BioControl 63 (1): 1-9. DOI: 10.1007/s10526-017-9862-4.

Miętkiewski R., Tkaczuk C., Żurek M., Geests L.P.S. 1994. Temperature requirements of four entomopathogenic fungi. Acta Mycologica 29 (1): 109-120.

Mikiciński A., Sobiczewski P. 2018. Perspektywy zastosowania bakterii w ochronie jabłoni i grusz przed zarazą ogniową (Erwinia amylovora). [Perspectives on the use of bacteria in the protection of apple and pear against fire blight (Erwinia amylovora)]. Progress in Plant Protection 58 (1): 68-75. DOI: 10.14199/ppp-2018-009.

Popławski Z. 1996. Słoma - jako nawóz organiczny. Instytut Uprawy Nawożenia i Gleboznawstwa, Puławy, 15 ss.

Ravensberg W.J. 2011. Roadmaps to the Succesfull Development and Commercialization of Microbial Pest Control Products for Control of Arthropods. Springer, Dordrecht, Heidelberg, 383 pp.

Rozporządzenie Parlamentu Europejskiego i Rady (WE) nr 1107/2009 z dnia 21 października 2009 r. dotyczące wprowadzania do obrotu środków ochrony roślin i uchylające dyrektywy Rady 79/117/EWG i 91/414/EWG (Dz. U. L 309 z 24.11.2009, s. 1).

Sandner H. 1971. Biologiczne metody ochrony roślin. Państwowe Wydawnictwo Rolnicze i Leśne, Warszawa, 201 ss.

Sharififard M., Mossadegh M.S., Vazirianzadeh B. 2012. Effects of temperature and humidity on the pathogenicity of the entomopathogenic fungi in control of the house fly, Musca domestica L. (Diptera: Muscidae) under laboratory conditions. Journal of Entomology 9 (5): 282-288. DOI: 10.3923/je.2012.282.288.

Sosnowska D. 2003. Możliwości zastosowania Pochonia chlamydosporia Zare et Gams oraz Paecilomyces lilacinus (Thom) Samson w biologicznym zwalczaniu mątwika burakowego (Heterodera schachtii Schmidt) i guzaków korzeniowych (Meloidogyne spp.). Rozprawy Naukowe Instytutu Ochrony Roślin, Zeszyt 9, 95 ss.

Sosnowska D. 2018. Pasożytniczy grzyb Isaria fumosorosea do biologicznego zwalczania mączlika szklarniowego w uprawach pomidora w szklarniach. Szklarnie, Tunele, Osłony 5: 33-35.

Sosnowska D., Banaszak H. 1998. Występowanie pasożytniczych grzybów w populacji mątwika burakowego (Heterodera schachtii Schmidt) w rejonie Torunia. [Occurrence of parasitic fungi on population of sugar beet nematode (Heterodera schachtii Schmidt) in Toruń region]. Progress in Plant Protection/Postępy w Ochronie Roślin 38 (2): 457-460.

Sosnowska D., Banaszak H. 2000. The effect of organic fertilizers on fungi parasitization of beet cyst nematode (Heterodera schachtii Schmidt) eggs in sugar beet cultivated in a three years rotation. [Wpływ nawożenia organicznego na spasożytowanie jaj mątwika burakowego (Heterodera schachtii) przez grzyby w trzyletnich rotacjach uprawy buraka cukrowego]. Journal of Plant Protection Research 40 (1): 73-79.

Steenberg T., Eilenberg J. 1995. Natural occurrence of entomopathogenic fungi on Aphids at an agricultural field site. Czech Mycology 48 (2): 89-96.

Tkaczuk C. 2008. Występowanie i potencjał infekcyjny grzybów owadobójczych w glebach agrocenoz i środowisk seminaturalnych w krajobrazie rolniczym. Wydawnictwo Akademii Podlaskiej. Rozprawa Naukowa 94, 160 ss.

Tomalak M., Sosnowska D. (red.). 2008. Organizmy pożyteczne w środowisku rolniczym. Instytut Ochrony Roślin - Państwowy Instytut Badawczy, Poznań, 95 ss. ISBN 978-83-89867-32-2.

Tomalak M., Zaremba M. 2004. Dostępność środków ochrony roślin dla rolnictwa ekologicznego i zasady ich rejestracji w Polsce. [Availability of plant protection agents for ecological agriculture and regulations on their registration in Poland]. Progress in Plant Protection/Postępy w Ochronie Roślin 44 (1): 462-472.

van Lenteren J.C., Bolckmans K., Köhl J., Ravensberg W.J., Urbaneja A. 2018. Biological control using invertebrates and microorganisms: plenty of new opportunities. BioControl 63 (1): 39-59. DOI: 10.1007/s10526-017-9801-4.

Yeo H., Pell J.K., Alderson P.G., Clark S.J., Pye B.J. 2003. Laboratory evaluation of temperature effects on the germination and growth of entomopathogenic fungi and on their pathogenicity to two aphid species. Pest Management Science 59 (2): 156-165. DOI: 10.1002/ps.622. 